\title{
Imaging findings of triple-negative breast cancer
}

\author{
Hiroko Kawashima
}

Published online: 9 December 2010

(C) The Japanese Breast Cancer Society 2010

The major principles of treatment for breast cancer patients are standardization and individualization. Namely, while employing evidence-based standard treatment as a pillar, details of individual treatment policies are established on the basis of the level of risk of each individual patient.

Breast cancer is comparatively sensitive to chemotherapy. In addition, hormone therapy is also effective for hormone receptor-positive breast cancers. Therefore, a multidisciplinary approach, which is directed both to the locoregional control (surgery and radiation therapy) and to the destruction of distant micrometastases (chemotherapy and hormone therapy), has become the main strategy in the treatment of breast cancer. Triple-negative breast cancers, which are negative for estrogen receptor (ER), progesterone receptor (PR), and human epidermal growth factor receptor 2 (HER2), are usually resistant to chemotherapy and endocrine therapy, and patients with these tumors have a poor prognosis [1-5].

In this special feature, the focus has been placed on triple-negative breast cancer, and 4 specialists have been asked to present their current findings, respectively, regarding the mammography and ultrasound features; MR imaging; $\mathrm{MR}$ and US imaging after neoadjuvant chemotherapy; and treatment strategies. A consensus of opinions may not be reached; however, it is hoped that this report assists in organizing the current views regarding triple-negative breast cancer, for doctors who are facing triple-negative breast cancer every day.

\section{References}

1. Bauer KR, Brown M, Cress RD, et al. Descriptive analysis of estrogen receptor (ER)-negative, progesterone receptor (PR)negative, and HER2-negative invasive breast cancer, the so-called triple-negative phenotype. Cancer. 2007;109:1721-8.

2. Rakha EA, Reis-Filho JS, Ellis IO. Basal-like breast cancer: a critical review. J Clin Oncol. 2008;26:2568-81.

3. Cheang MG, Voduc D, Bajdik C, et al. Basal-like breast cancer defined by five biomarkers has superior prognostic value than triple-negative phenotype. Clin Cancer Res. 2008;14:1368-76.

4. Haffty BG, Yang Q, Reiss M, et al. Locoregional relapse and distant metastasis in conservatively managed triple negative earlystage breast cancer. J Clin Oncol. 2006;24:5652-7.

5. Mersin H, Yildirim E, Berberoglu U, et al. The prognostic importance of triple negative breast carcinoma. Breast. 2008; 17:341-6.
H. Kawashima ( $\square)$

Department of Quantum Medical Technology, Graduate School of Medical Science, Kanazawa University, 5-11-80 Kodatsuno, Kanazawa 920-0942, Japan

e-mail: hirokok@med.m.kanazawa-u.ac.jp 